\title{
IMPLEMENTATION OF ARTIFICIAL INTELLIGENCE IN ESTIMATING PRIME COSTS OF PRODUCING MACHINE ELEMENTS
}

\author{
Dariusz Więcek
}

S u m m a r y

Using methods of planning automating of production processes as well as artificial intelligence, the methods presented in this paper were constructed for identifying the set value of manufacturing process parameters, which are key to evaluating the costs of the designed elements. The proposed solutions were adapted for systems used under the conditions of unit and small-batch production.

Keywords: artificial intelligence, cost estimation, activity based costing

\section{Zastosowanie sztucznej inteligencji w szacowaniu kosztów własnych \\ wytwarzania elementów maszyn}

$$
\text { Streszczenie }
$$

W artykule przedstawiono metody pozwalające na określenie zbiorów wartości parametrów procesu wytwarzania. Mogą stanowić podstawę szacowania kosztów produkcji projektowanych elementów. Stosowano metody automatyzacji projektowania procesów produkcyjnych i metody sztucznej inteligencji. Zaproponowane rozwiązania dostosowano do systemów produkcyjnych funkcjonujących w warunkach produkcji jednostkowej i małoseryjnej.

Słowa kluczowe: sztuczna inteligencja, szacowanie kosztów, rachunek kosztów działań

\section{Introduction}

Production process design involves numerous heuristic activities, due to the lack of a mathematical model of the designed object (e.g. variables are not defined, relations between variables are unknown), or the lack of possibilities of full calculations with an existing model. In such situations, different researchers adopted different advanced techniques and approaches such as feature or solid model based design, object oriented programming, manufacturing databases, and used advanced computing methods including artificial intelligence (AI) [1].

Address: Dariusz WIĘCEK, Ph.D. Eng., University of Bielsko-Biała, Department of Production Engineering, Faculty of Mechanical Engineering and Computer Sciences, Willowa 2, 43-309 Bielsko-Biała, e-mail: wiecekd@ath.bielsko.pl 
Among others, the following methods of artificial intelligence, related to production process design, are mentioned: Artificial Neural Networks, Expert Systems, Genetic Algorithms.

Expert Systems (ES) give the possibility of solving specialized problems which require professional expertise, which means that they can replace an expert in a given field, often without a need of expert's support during program operation. A characteristic feature of this system is a division of knowledge gained from an expert, called knowledge base, and the rest of the system containing, among others, mechanisms of reasoning on the basis of knowledge resources from a given domain. [2,3]. Expert Systems can be generally divided into three categories [4]:

- advisory - systems presenting the user certain solutions, which are evaluated in order to choose the most adequate one, or to ask for another solution,

- taking decisions without human control (dictatorial) - systems, which do not consult end results with the user,

- criticizing - are characterized by taking input values related to the given problem and possible solution.

The role of the system consists in analysing the problem and commenting on the proposed solution. Expert Systems are able to: gather complete knowledge from a given domain and update it constantly, copy the way of thinking of an expert, which results in offering decisions and providing their variants, explain the way of thinking of the user to the adopted solutions, communicate in a language comfortable for the user $[4,5]$.

The method of knowledge representation should allow a simple, concise, complete, comprehensible and clear knowledge record. To present knowledge, it is necessary to gather information from a given domain, formulate it in form of statements and code it properly. The most popular ways of knowledge representation include methods based on the use of formal logics (sentence calculus, predicate calculus) and informal ways, i.e.: semantic networks, frameworks, statements, rules [2,3].

\section{The proposed method of estimation of cost of machine elements on the stage of production preparation}

The proposed method of cost estimation for machine elements belongs to the methods of cost calculation. It bases on a formalized description of information with constructional, manufacture and organizational features related to a designed element, the method of design automation of technological process design (variant design, generation design), which uses the methods of group technology, artificial intelligence (pattern recognition, expert systems), and the model of production cost estimation for machine elements based on Activity 
Based Costing $[3,5]$. These assumptions locate the proposed method among hybrid group (linking the above mentioned methods) of cost calculation methods.

The course of action in the proposed method was divided into several phases, which use information generated on different stages of production process design aided by the CAx systems or information stored in databases of these systems [5]. The assumed model of procedure and location of subsequent phases in functional areas of the CAx systems was presented in Fig. 1.

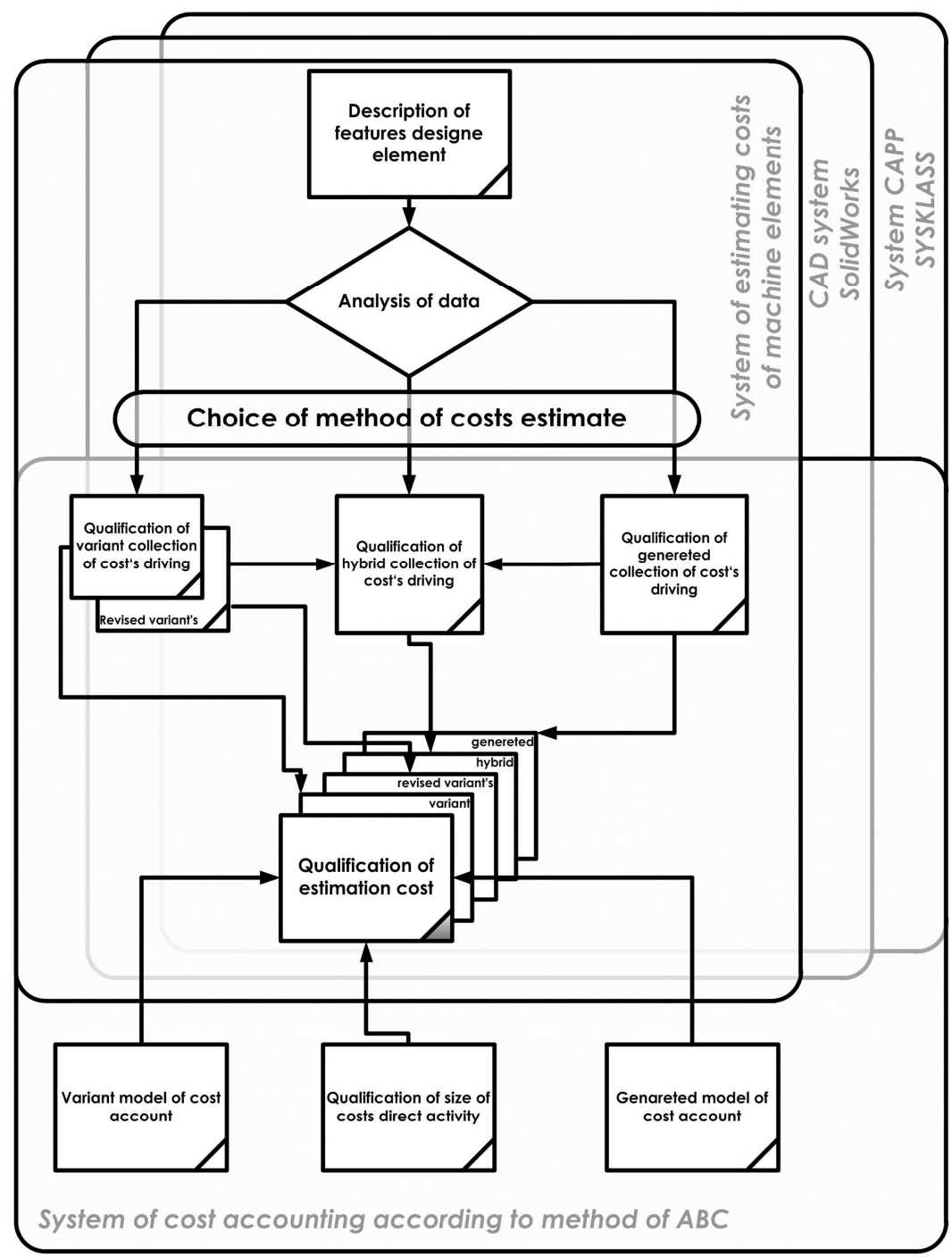

Fig. 1. General model of the procedure in the proposed method 


\section{A model of estimation of machine elements production cost}

Production cost of a product covers the ensemble of activity cost, as a consequence of which a finished product of a given value is created from raw material or materials. The complexity of manufacturing is determined by the level of difficulty and constructional and manufacture connections taking place between different levels of a product (sets, subsets, elements) [6,7].

Values of parameters related to manufacturing processes designed by means of the variant method or generation method do not relate strictly to the variables influencing the value of particular components of production cost. Hence, it is necessary to determine a set of cost's driving factors: that is factors which equivocally determine the value of variables related to the separated cost components and the way of their determination. This task may be realized in three ways, by means of the variant, generation or hybrid approach.

In further elaboration the hybrid method of estimation of cost's driving factors will be discussed.

The presented method relates to generating a set of parameters of a manufacturing process connected with features which describe the designed element (COPE). Particularly the module, on the basis of the COPE set and values of parameters describing the designed element, generating a set of values for production process parameters. The values are connected with sub-activities, which are here understood as technological treatments needed for a given feature to obtain qualities complying with constructional assumptions. The functioning outline of this module is shown in Fig. 2. On the basis of PN-norms a treatment is a part of operation related to machining its surface with one tool and fixed machining parameters. The basic tool here is a dedicated expert system. According to the assumptions of expert systems' structure, a database of the analysed objects was established in the proposed system in the form of: COPE sets $-\boldsymbol{F} \boldsymbol{P}_{\boldsymbol{\delta}}^{e p}$, sets of values for parameters describing COPE $-\boldsymbol{V P P T ^ { e p }}$.

A very significant stage of database design is determining the way of knowledge representation. On the basis of the conducted analysis, knowledge representation was accepted in form of frames and rules. Representation of technological knowledge in form of frames was dictated by plurality and diversity of the gathered information for particular COPE.

\section{Generating a set of sub-activities for the transformation process-technological operation}

The proposed base of technological knowledge stores basic technological knowledge which was gained from an expert. The knowledge gathered in the base has to enable determining the values of manufacturing process 


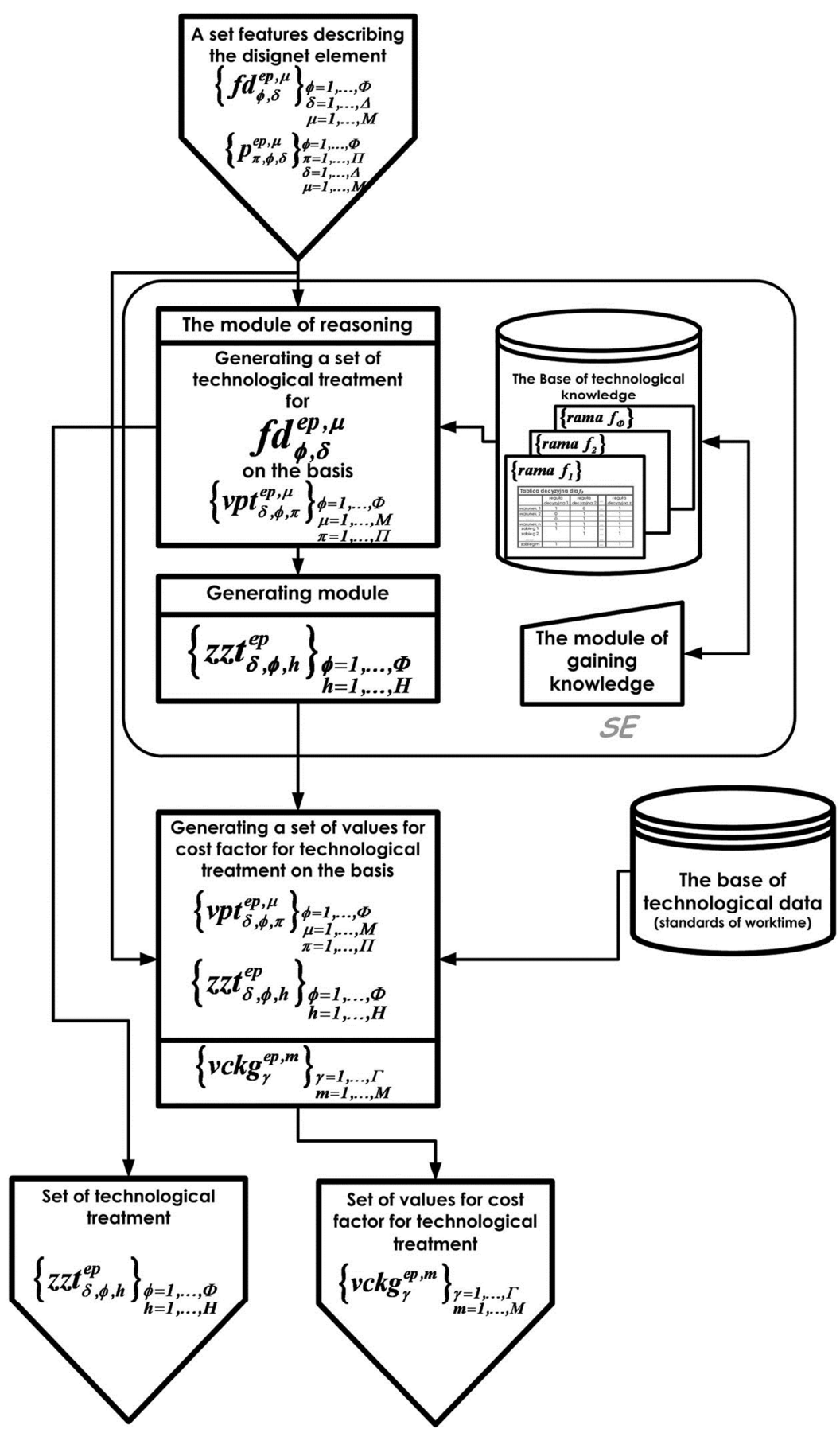

Fig. 2. An outline of generating parameter values for a manufacturing process for particular COPE 
parameters, so it relates information about sets of technological treatments for a given feature, required to achieve the assumed values of usable parameters in the accepted variant of a manufacturing process, and for each treatmentinformation about production workplace, as well as grouping workers adequately for the given technological treatment.

In the knowledge base proposed in the paper, premises are created on the basis of COPE parameter values and value tolerance of these parameters. Each premise is a logical sentence, which is a conjunction of phrases checking if parameter value is included in the assumed interval and if tolerance of a given value is included in the estimated interval. Logical value of a premise assumes a logical result of a task determined for it, or its negation, according to the rule where the premise is considered. Logical value of a premise may assume the following values:

- 1 - if truthfulness of a premise is significant in the given rule,

- 0 - if falseness of a premise is significant in the given rule,

- ," - if a premise is insignificant in the given rule.

Each rule in the proposed knowledge base is connected with a set of technological treatments necessary to achieve the required constructional parameters of a considered feature. Thus, we can say that each rule is a variant of a manufacturing process.

The value of activities - stating if a given activity (technological treatment) should be carried out, if a given rule is fulfilled, takes values connected to the order of appearance of a given treatment in a process variant (rule) or NULL value if a given treatment is not present in the variant.

Acceptance of a given variant (that is fulfilling the given rule) takes place if all significant premises for this rule took the value determined in the part of decision table which includes values of premises. Table 1 presents a fragment of sample decision table for the frame connected to COPE - simple through-holes.

Apart from previously discussed elements, in a table with the following construction also the elements which support the creation of logical conditions forming premises were separated. The presented table includes information on parameters (column: param), whose values are considered in logical conditions, as well as information on interval boundaries of values taken by these parameters together with their tolerance (columns: od_val, do_val, od_IT, do_IT).

The proposed way of knowledge representation required building a module of gaining the needed knowledge for the accepted way of its interpretation.

The structure of the module of knowledge acquisition is closely connected with the adopted method of its acquisition. The paper proposes a direct method of knowledge acquisition called 'learning by heart'. The designed module of knowledge acquisition is a dialogue interface, through which an expert records his knowledge about creating such sets of technological treatment (variants of 
manufacturing) $\mathrm{w}$ the given factory conditions and according to parameter values adopted through COPE which describe the elements of a given type of production.

A variant of the manufacturing process should allow achieving constructional parameters assumed in the course of construction design process. The module of knowledge acquisition was designed in such a way that an expert could use information about all parameters describing the considered feature and about parameters describing the remaining features which create the description of elements of a given type.

On the basis of sets of information gathered in this way, decision tables are created, which are used in the reasoning process that is the process of choosing the variant of treatment sets for the given feature.

The proposed expert system adopted a method of 'ahead' reasoning (progressive). This method assumes that on the basis of known rules, premises and facto, the system generates new facto, for which there is a fact in the knowledge base, which is an answer to the hypothesis, or there is no possibility of finding solution on the basis of known generated facts $[8,9]$.

Table 1. Decision table for a frame \{frame F76_k01\} - simple through-holes (fragment)

\begin{tabular}{|c|c|c|c|c|c|c|c|c|}
\hline \multicolumn{9}{|c|}{ frame F76_k01\}-simple through-holes } \\
\hline ID & Parameter description & od_val & do_val & od_IT & do_IT & w1 & w2 & w3 \\
\hline p1 & $\begin{array}{l}\text { Simple through-holesint. } \\
\text { diameter. D. }\end{array}$ & 0 & 26 & 20 & 12 & & & 1 \\
\hline p2 & $\begin{array}{l}\text { Simple through-holes int. } \\
\text { diameter. D. }\end{array}$ & 26,01 & 40 & 20 & 12 & 1 & & \\
\hline p3 & $\begin{array}{l}\text { Simple through-holes int. } \\
\text { diameter. D. }\end{array}$ & 41 & 500 & 20 & 12 & & 1 & \\
\hline $\mathrm{p} 4$ & Simple through-holes length $\mathrm{L}$ & 0 & 60 & 20 & 12 & 1 & 1 & 1 \\
\hline p5 & Simple through-holes roughness & 0,64 & 12,5 & 0 & 0 & 1 & 1 & 1 \\
\hline p6 & Round bars type & 0 & 4 & 0 & 0 & 1 & 1 & 1 \\
\hline $\mathrm{d} 1$ & \multicolumn{5}{|c|}{$\begin{array}{c}\text { Treatment: turning reaming roughly / workplace: } 0440102 \text { /worker: } \\
\text { turner }\end{array}$} & 3 & & 2 \\
\hline $\mathrm{d} 2$ & \multicolumn{5}{|c|}{$\begin{array}{l}\text { Treatment: turning drill-rebor / workplace: } 0440102 \text { / worker: } \\
\text { turner }\end{array}$} & 2 & 2 & \\
\hline $\mathrm{d} 3$ & \multicolumn{5}{|c|}{$\begin{array}{l}\text { Treatment: turning drill with machine with feed / workplace: } \\
\qquad 0440102 \text { / worker: turner }\end{array}$} & 1 & 1 & 1 \\
\hline d4 & \multicolumn{5}{|c|}{$\begin{array}{l}\text { Treatment: shaping coarse. Ra3.2 / workplace: } 0440102 \text { / worker: } \\
\text { turner }\end{array}$} & & 4 & \\
\hline d5 & \multicolumn{5}{|c|}{$\begin{array}{c}\text { Treatment: turn roughly longitudinally / workplace: } 0440102 \text { / worker: } \\
\text { turner }\end{array}$} & & 3 & \\
\hline
\end{tabular}


In the considered aspect, the aim is to check if the given variant of a technological process may be applied to the determined COPE.

Because there are different numbers of premises, a specificity strategy of reasoning steering was used. The specificity strategy assumes that rules are checked according to the number of premises in the given rule, starting from the highest number. With the same number of premises the rule is chosen, which contains the smaller number of variables $[9,10]$.

\section{Example of estimating cost for different variants of production of the selected element}

In order to illustrate possibilities of change analysis of self cost of the designer element in the course of the construction record process for the element presented on Figure 3, an analysis of estimating cost change of this element was carried out during subsequent changes in creating a construction record.

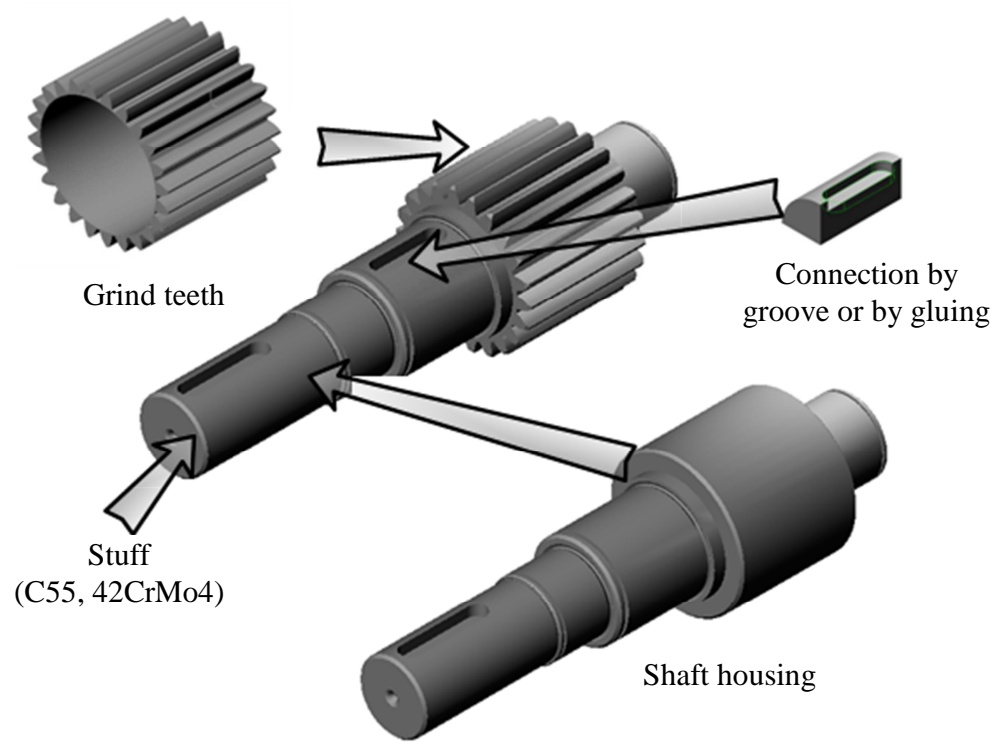

Fig. 3. Features of a sample designed element

The first stage of realization of manufacturing self cost estimation on the stage of design for an ample element is determination of variants of constructional representation creation. A set of settled variants is presented in Fig. 4. 


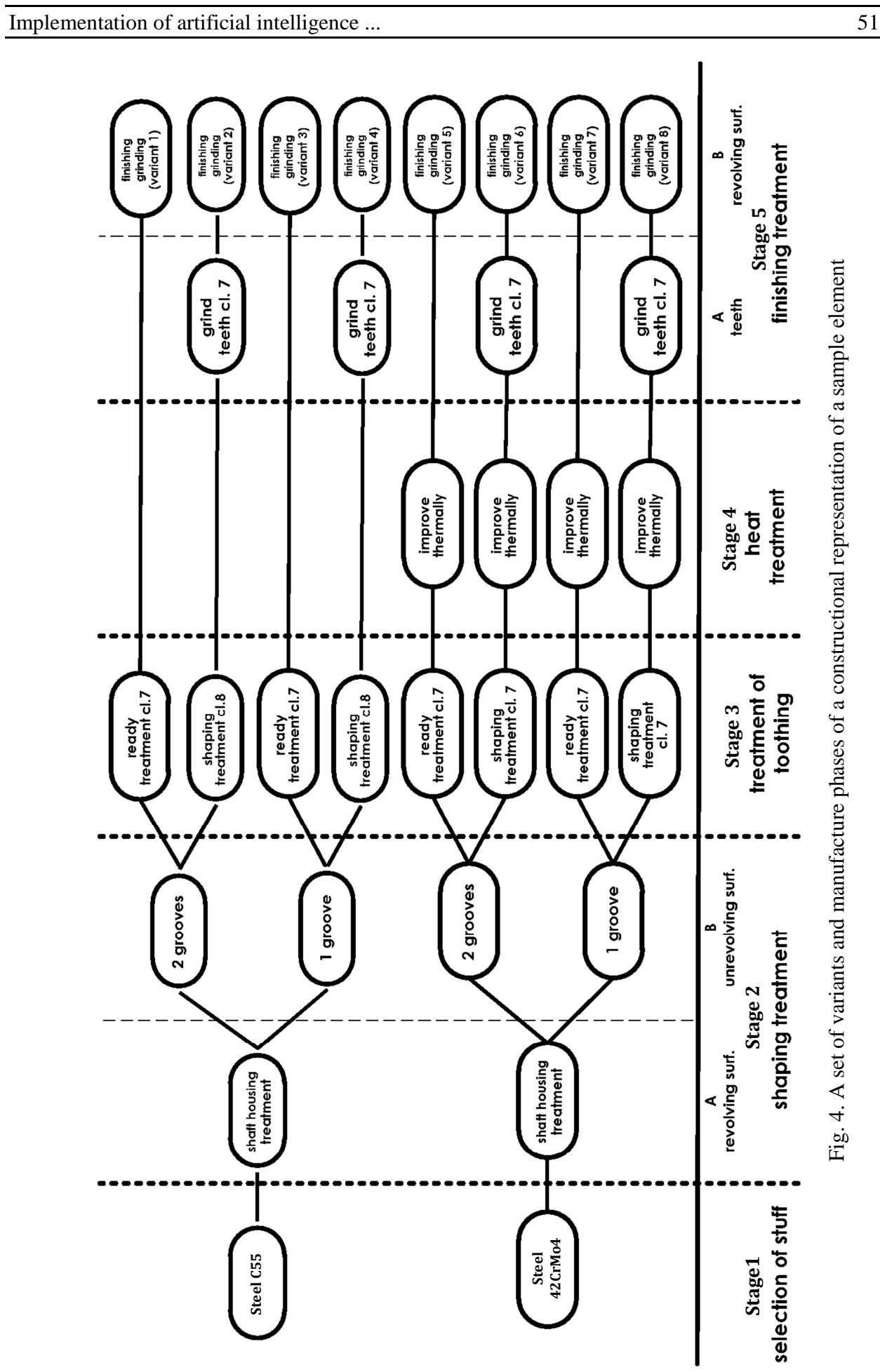


Final estimating cost of particular variants of manufacture of different constructional representations of the ample element was presented in Fig. 5.

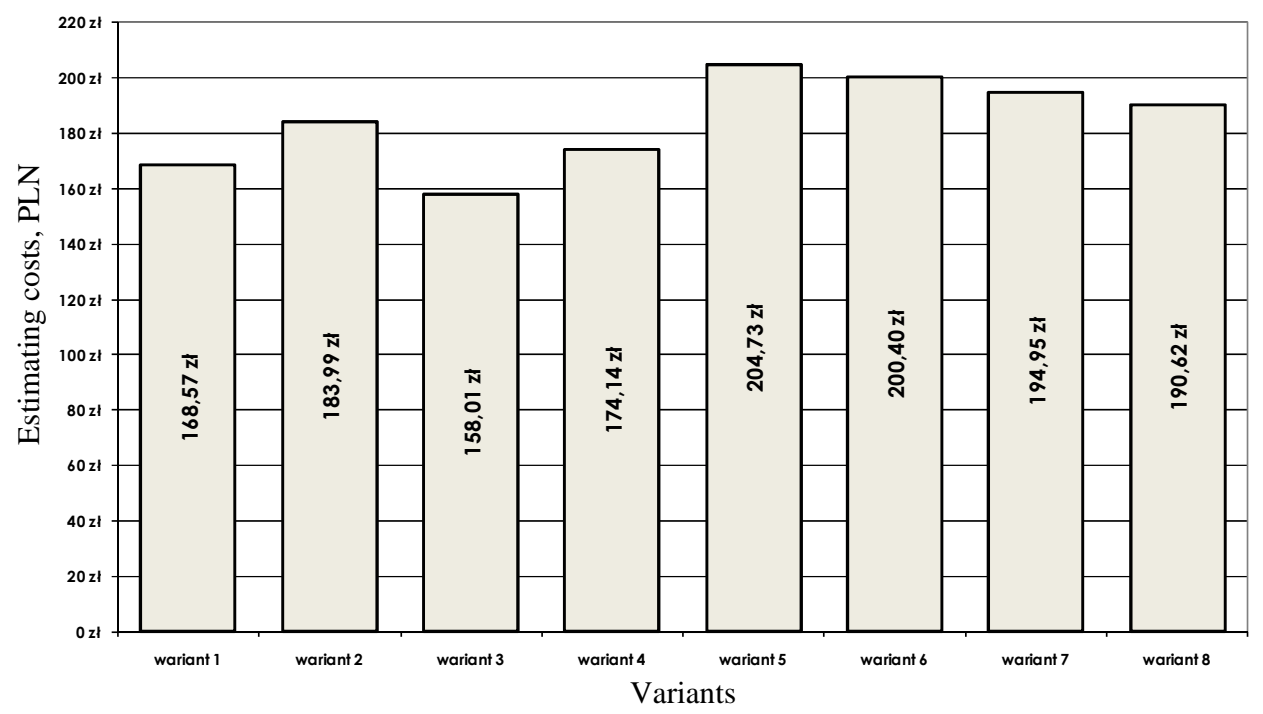

Fig. 5. A set of estimating self costs of manufacture for all variants of element production

\section{Conclusions}

On the basis of the conducted research, the following conclusions have been drawn:

- The use of construction basing on parametric constructional features accelerates the process of creating the writes of construction, but it also permits automatically to execute in figures the file of features describing the writes of information on the projected units as well as the files of value of parameters describing the features of elements required on further design stages.

- The Activity Based Costing delivers the particulars about real costs of products, realized processes and connected activities which constitute the basis for decision-making in the production process management.

- The correct determination of costs of the projected elements is dependent on the assumed model of cost account. The settlement of cost variables as function of the parameter values of the features describing the projected elements permits automatic costs determination on the ground of the description of the projected element.

- The methods of pattern recognition on the ground of the collection of constructional, manufacturing and organizational features describing the 
projected elements lets us find such element whose process of manufacturing contains the required activity for the realization of the established construction.

- Having at our disposal the collection of parameter values of features, we can, using the expert system, generate the collection of activities and subactivities of manufacturing process, necessary to obtain the assumed parameters of the projected element, as well as required from the point of view of the manufacturing of a given element.

- Application of the description basing on functional features of the projected elements permits an automatic identification of the newly projected elements, as well as for the division of the already existing elements into groups on the ground of any number of particular and organic constructional production and organizational data.

\section{References}

[1] R. STRYCZEK: Computational intelligence in computer aided process planning - a review. Advances in Manufacturing Science and Technology, 31(2007)4, 77-89.

[2] P. HARMON, D. KING: Expert Systems. New York, John Wiley \& Sons Inc. 1985.

[3] E. TURBAN: Expert System and Applied Artificial intelligence. MaxwellMcmillan, New York 1992.

[4] J.J. MULAWKA: Systemy ekspertowe. PWN, Warszawa 1996.

[5] R. KNOSALA (red.): Zastosowania metod sztucznej inteligencji w inżynierii produkcji. WNT, Warszawa 2002.

[6] B. LOGAR, J. PEKLENIK: Feature-Based Part Database Design and Automacic Forming of Part Families for GT. Annals of the CIRP, 40(1991)1, 153-156.

[7] M. BRZEZIŃSKI: Organizacja i sterowanie produkcją. Agencja Wydawnicza Placet, Warszawa 2002.

[8] J.P. IGNIZIO: An introduction to expert systems. McGraw-Hill, New York 1999.

[9] Y.M. CHEN, C.L. WEI: Computer-aided feature-based design for Net Shape Manufacturing. Computer Integrated Manufacturing Systems, 10(1997)2, 147-164.

[10] T.C. CHANG: Expert process planning for manufacturing. Addison-Wesley Publishing Company, Inc., New York 1990. 